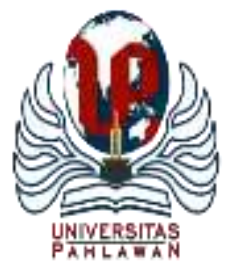

Edukatif : Jurnal Ilmu Pendidikan Volume 3 Nomor 6 Tahun 2021 Halm 4719 - 4730

EDUKATIF: JURNAL ILMU PENDIDIKAN

Research \& Learning in Education

https://edukatif.org/index.php/edukatif/index

\title{
Konsep Pendidikan Agama Islam Perspektif Pemikiran Syekh Ahmad Surkati
}

\author{
Asep Supriatna ${ }^{1 凶}$, Vina Febiani Musyadad ${ }^{2}$, Alfian Syach $^{3}$, Diah Widiawati ${ }^{4}$ \\ STIT Rakeyan Santang, Indonesia ${ }^{1,2,3,4}$ \\ E-mail : aasepstea@gmail.com ${ }^{1}$, vinamusyadad@gmail.com ${ }^{2}, \underline{\text { alfyansyach38@gmail.com }}^{3}$, \\ diahwidiawati51@gmail.com $^{4}$
}

\begin{abstract}
Abstrak
Pendidikan Islam memiliki tugas penting untuk mengembangkan kualitas sumber daya manusia (SDM) agar umat Islam dapat berperan aktif dan tetap bertahan serta bersaing di era globalisasi. Syekh Ahmad Surkati merupakan tokoh yang besar dalam pembaharuan pemikiran Islam di Indonesia terutama dalam bidang pendidikan, namun namanya masih jarang disebut dalam wacana sejarah pergulatan pemikiran Islam di Indonesia. Tujuan penelitian ini adalah untuk mengetahui konsep pendidikan Islam yang digagas oleh Syekh Ahmad Surkati secara mendalam, karena pemikiran beliau banyak mempengaruhi dunia Pendidikan Islam di Indonesia. Jenis penelitian yang dilakukan dalam penelitian ini adalah studi kepustakaan (library research). Syekh Ahmad Surkati merupakan tokoh pembaharu dunia pendidikan Islam, ini terbukti dengan adanya penjenjangan dalam intuisi pendidikan yang dilakukan oleh Syekh Ahmad Surkati, yang sebelumnya belum pernah ada di Indonesia. Syekh Ahmad Surkati juga merupakan pelopor terbentuknya sistem kelembagaan dalam dunia pendidikan. Ini sebuah kemajuan dalam dunia pendidikan. Besar kiranya kontribusi Syekh Ahmad Surkati dalam membina dan memajukan serta membenahi sistem pendidikan yang berkembang di Indonesia.

Kata kunci: Konsep Pendidikan, Pendidikan Islam, Ahmad Surkati
\end{abstract}

\begin{abstract}
Islamic education has an important task to develop the quality of human resources (HR) so that Muslims can play an active role and survive and compete in the era of globalization. Sheikh Ahmad Surkati is a big figure in the renewal of Islamic thought in Indonesia, especially in the field of education, but his name is still rarely mentioned in the discourse of the history of the struggle of Islamic thought in Indonesia. The purpose of this study is to find out the concept of Islamic education initiated by Sheikh Ahmad Surkati in depth, because his thoughts have influenced the world of Islamic education in Indonesia. The type of research conducted in this research is library research. Syekh Ahmad Surkati is a reformer in the world of Islamic education, this is evidenced by the existence of levels in educational intuition carried out by Sheikh Ahmad Surkati, which had never existed in Indonesia before. Sheikh Ahmad Surkati was also a pioneer in the formation of an institutional system in the world of education. This is an advance in the world of education. Shaykh Ahmad Surkati's contribution would be great in fostering and advancing and fixing the developing education system in Indonesia.
\end{abstract}

Keywords: Concept of Education, Islamic Education, Ahmad Surkati

Copyright (c) 2021 Asep Supriatna, Vina Febiani Musyadad, Alfian Syach, Diah Widiawati

$\triangle$ Corresponding author

Email : aasepstea@gmail.com

DOI : https://doi.org/10.31004/edukatif.v3i6.1534

ISSN 2656-8063 (Media Cetak)

ISSN 2656-8071 (Media Online)

Edukatif : Jurnal Ilmu Pendidikan Vol 3 No 6 Tahun 2021 p-ISSN 2656-8063 e-ISSN 2656-8071 
4720 Konsep Pendidikan Agama Islam Perspektif Pemikiran Syekh Ahmad Surkati - Asep Supriatna, Vina Febiani Musyadad, Alfian Syach, Diah Widiawati

DOI: https://doi.org/10.31004/edukatif.v3i6.1534

\section{PENDAHULUAN}

Sudah maklum bahwa pendidikan merupakan usaha sadar yang dilakukan oleh anggota keluarga, masyarakat dan pemerintah, melalui kegiatan bimbingan, pengajaran, dan latihan, yang berlangsung di sekolah dan di luar sekolah sepanjang hayat, untuk mempersiapkan peserta didik agar dapat memainkan peranan dalam berbagai lingkungan hidup secara tepat di masa yang akan datang. Pendidikan adalah pengalaman-pengalaman belajar terprogram dalam bentuk pendidikan formal dan non formal, dan informal di sekolah, dan di luar sekolah, yang berlangsung seumur hidup yang bertujuan optimalisasi pertimbanagan kemampuan-kemampuan individu agar di kemudian hari dapat memainkan peranan hidup secara tepat.

Dalam perumusan dasar pendidikan Islam, yang harus menjadi pertimbangan selain falsafah suatu bangsa, juga pertimbangan-pertimbangan teologis seorang muslim. Islam yang diyakini mengandung kebenaran mutlak yang bersifat fundamental, universal dan eternal, secara akidah menjadikan manusia sesuai dengan fitrahnya.

Dapat dirasakan bahwa eksistensi Pendidikan Islam saat ini mengalami masa intellectual deadlock. Diantara indikasinya adalah; pertama, minimnya upaya pembaharuan, dan kalau pun ada masih kalah cepat dengan perubahan sosial, politik dan kemajuan iptek. Kedua, praktek pendidikan Islam sejauh ini masih memelihara warisan yang lama dan tidak banyak melakukan pemikiran kreatif, inovatif dan kritis terhadap isu-isu aktual. Ketiga, model pembelajaran pendidikan Islam terlalu menekankan pada pendekatan intelektualisme verbalistik dan menegasikan pentingnya interaksi edukatif dan komunikasi humanistik antara guru-murid. Keempat, orientasi pendidikan Islam menitik beratkan pada pembentukan ' $a b d$ atau hamba Allah dan tidak seimbang dengan pencapaian karakter manusia muslim sebagai khalifah fi al-ardl. Di sisi lain pendidikan Islam mengemban tugas penting, yakni bagaimana mengembangkan kualitas sumber daya manusia (SDM) agar umat Islam dapat berperan aktif dan tetap survive di era globalisasi. Dalam konteks ini Indonesia sering mendapat kritik, karena dianggap masih tertinggal dalam melakukan pengembangan kualitas manusianya. (Badar, 2012)

Pendidikan Islam mengemban tugas penting, yakni bagaimana mengembangkan kualitas sumber daya manusia (SDM) agar umat Islam dapat berperan aktif dan tetap survive di era globalisasi. Dalam konteks ini Indonesia sering mendapat kritik, karena dianggap masih tertinggal dalam melakukan pengembangan kualitas manusianya. Dari segi kuantitas Indonesia memiliki sumber daya manusia melimpah yang mayoritas beragama Islam.

Kompleksnya persoalan pendidikan di satu sisi dan tuntutan meningkatkan kualitas sumber daya manusia di sisi lain menyebabkan persoalan pendidikan tetap menarik untuk dibahas dengan harapan pembahasan ini mampu memunculkan solusi alternatif dalam mengembangkat kualitas sumber daya manusia lewat jalur pendidikan Islam. (Jahar, 2018)

Pada masa pergerakan banyak bermunculan sebagai tokoh pelopor pergerakan pendidikan Islam di Indonesia. Menguatnya gerakan Islam juga dipengaruhi semangat Pan Islamisme Timur Tengah, terutama setelah banyaknya para jamaah haji yang pulang dari Mekah dan para pemuda Muslim yang belajar di sana. Sebut misalnya KH. Hasjim Asy'ari (pendiri Nahdhatul Ulama, NU) dan KH. Muhammad Dahlan (pendiri Muhammadiyah), Syekh Achmad Chatib dari Minangkabau dan Syekh al-Banjari dari Banjarmasin. Dari kelompok Arab, pengaruh Arab Hadrami juga sangat penting terutama dalam bidang Pendidikan dan dakwah, sebut misalnya Jamiatul Khayr dan al-Irsyad oleh Ahmad Surkati. Berawal dari sinilah muncul kemudian ormas Islam yang lingkup kegiatannya tidak saja pendidikan, tetapi juga dakwah, sosial, ekonomi dan kesehatan. (Jahar, 2018)

Sheykh Ahmad Surkati adalah seorang ulama yang berasal dari Sudan, ia merupakan pendiri dan tokoh utama gerakan al-Irsyad yang memiliki pengaruh besar pada pembaruan keagamaan dan pendidikan di Indonesia. Menurutnya, pendidikan adalah kunci kemajuan peradaban manusia. Ia pun memelopori budaya 
4721 Konsep Pendidikan Agama Islam Perspektif Pemikiran Syekh Ahmad Surkati - Asep Supriatna, Vina Febiani Musyadad, Alfian Syach, Diah Widiawati

DOI: https://doi.org/10.31004/edukatif.v3i6.1534

ilmiah di kalangan Umat Islam Indonesia dengan merujuk kepada al-Qur'an dan al-Sunnah yang diharapkan bisa membentuk pola pikir berkarakter Islam. Melalui pendidikan dan budaya ilmiah yang menekankan rasionalitas dalam memahami ajaran agama, Surkati membangkitkan kesadaran Muslim Indonesia dari keterpurukan akibat penjajahan dan menciptakan sebuah pemahaman yang dapat diterima oleh dua komunitas Islam, yaitu Indonesia dan Arab. Pemahaman itu menyangkut penekanan nilai-nilai universal Islam seperti kesetaraan dan persamaan kedudukan umat Islam dalam beragama.(Nurmaningtyas, 2013)

Perjuangan Ahmad Surkati melalui pendidikan dan budaya ilmiah pada abad ke-20 masih relevan hingga kini. Di tengah beragam tantangan era globalisasi, masyarakat Indonesia membutuhkan pencerahan yang dapat menuntun mereka untuk berpartisipasi aktif dalam percaturan kemajuan dunia, namun tetap dalam bingkai ajaran agama dan nilai-nilai khas Indonesia. Besarnya peranan dan pengaruh Surkati terhadap perkembangan keislaman dan pendidikan Islam serta bagaimana pendidikan yang diselenggarakannya dapat menimbulkan kesadaran kebangsaan.

Jami'atul Khayr, Al-Irsyad dan Muhammadiyah adalah contoh gerakan Islam yang memulai mengembangkan pendidikan dan dakwah di Jawa. Muhammadiyah sendiri pada 1912-1920 mulai mengembangkan aktivitasnya dalam bidang pendidikan dan kesejahteraan sosial. Dari lembaga pendidikan ini kemudian lahir gerakan-gerakan sosial yang lebih luas terutama dalam meningkatkan harkat dan derajat masyarakat. Sejak mulai pemerintahan Jepang, ormas Islam mulai terlibat dalam kegiatan politik disamping pendidikan dan dakwah, terutama ketika Jepang menfasilitasi berdirinya Masyumi (Majlis Syura Muslimin Indonesia).

Penyelenggaraan pendidikan di Indonesia menurut UU Nomor 20 Tahun 2003 pasal 1 ayat (2) disebutkan bahwa suatu Pendidikan Nasional adalah pendidikan yang berdasarkan Pancasila dan UndangUndang Dasar 1945 yang berakar pada nilai-nilai agama, kebudayaan nasional Indonesia dan tanggap terhadap tuntutan perubahan zaman. Tidak bisa dipungkiri bahwa pendidikan Islam, baik sebagai sistem maupun institusinya, merupakan warisan budaya bangsa, yang berurat berakar pada masyarakat bangsa Indonesia. Dengan demikian jelas bahwa pendidikan Islam akan merupakan bagian integral dari sistem pendidikan nasional.

Mengenai konsep pengembangan Pendidikan Islam, Allah Swt. memberikan isyarat dalam al Quran surat Al-Baqarah ayat 31 yang berbunyi:

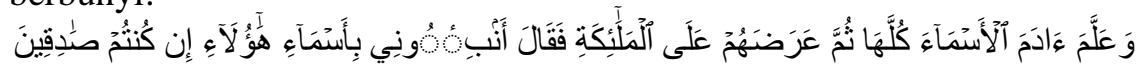

"Dan Dia mengajarkan kepada Adam Nama-nama (benda-benda) seluruhnya, kemudian mengemukakannya kepada Para Malaikat lalu berfirman: "Sebutkanlah kepada-Ku nama benda-benda itu jika kamu mamang benar orang-orang yang benar!" (Q.S. Al-Baqarah: 31)

Makna yang terkandung dalam ayat tersebut dalam konteks pendidikan Islam adalah upaya untuk mengaktualisasikan sifat-sifat kesempurnaan yang telah dianugerahkan oleh Allah kepada manusia.

Dalam penerapannya metode pendidikan harus memperhatikan permasalahan individu dan sosial para peserta didik dan pendidik tentunya, dalam metode pendidikan Islam khususnya ada dasar-dasar umum yang harus diterapkan yaitu: 1) Dasar religious, yang menitik beratkan bahwa manusia adalah mahluk religious dan agama adalah dasar sebagai metode pengajaran bagi pendidik. 2) Dasar filosofis, yang memandang manusia adalah mahluk rasional, sehingga segala sesuatu yang menyangkut perkembangannya didasarkan pada sejauh mana kemampuan berpikirnya dapat dikembangkan sampai titik maksimal perkembangannya. 3) Dasar sosiokultur, yang tertumpu bahwa manusia adalah mahluk yang bermasyarakat dan berkebudayaan dan disebut juga homosapiens, dengan demikian pengaruh lingkungan dan kebudayaannya sangat besar bagi proses pendidikan individualnya. 4) Dasar scientific, yang berpandagan bahwa manusia memliki kemampuan mencipta (kognitif) dan berkemauan (konatif) dan merasa (afektif) sehingga pendidikan harus dapat mengembangkan kemampuan analitis dan reflektif dalam berpikir. (Sugeng Kurniawan, 2014)

Prinsip yang harus ditegakkan dalam bangunan metode pembelajaran amat banyak sekali, diantaranya 
4722 Konsep Pendidikan Agama Islam Perspektif Pemikiran Syekh Ahmad Surkati - Asep Supriatna, Vina Febiani Musyadad, Alfian Syach, Diah Widiawati

DOI: https://doi.org/10.31004/edukatif.v3i6.1534

yang terpenting adalah; 1) prinsip kesesuaian psikologi perkembangan jiwa anak; 2) prinsip kesesuaian dengan bakat dan kecenderungan si anak; 3) prinsip kesesuaian dengan bidang ilmu yang akan diajarkan; 4) prinsip kesesuaian dengan lingkungan di mana ilmu tersebut akan disampaikan; 5) prinsip kesesuaian dengan tujuan dan cita-cita pendidikan yang akan dilaksanakan; 6) prinsip kesesuaian dengan sarana dan prasarana pengajaran yang tersedia; 7) prinsip kesesuaian dengan tingkat kecerdasan peserta didik; dan 8) prinsip kesesuaian dengan kebutuhan masayarakat terhadap ilmu yang akan diajarkan. (Tabak, 2014)

Secara filosofis, mengisyaratkan bahwa proses pendidikan Islam yang terkandung dalam Istilah AlTarbiyyah, memuat empat unsur, yaitu: 1) Memelihara dan menjaga fitrah anak didik menjelang dewasa, 2) Mengembangkan seluruh potensi menuju kesempurnaan, 3) Mengarahkan seluruh fitrah menuju kesempurnaan, dan 4) Melaksanakan pendidikan secara bertahap. (Halim, 2014)

Menurut Ahmad Surkati sistem pendidikan harus mencerminkan kebutuhan masyarakat. Bahwa pendidikan harus mampu memberikan perbaikan kondisi masyarakat secara lahir dan batin. Sistem pendidikan yang ideal menurutnya adalah sistem pendidikan yang ada mengandung dimensi ilahiyah dan dimensi insaniyah. Ahmad Surkati menyatakan bahwa sistem pendidikan hendaknya mencerminkan kebutuhan masyarakat. Dalam arti pendidikan hendaknya mampu mengakomodasi kebutuhan yang ada dalam masyarakat, peningkatkan taraf hidup secara menyeluruh baik jasmani dan rohani dan yang tidak kalah penting adalah peningkatan pendidikan, di mana sistem pendidikan tersebut harus bersinergi dengan nilai-nilai ketuhanan dan kemanusiaan. Dapat diambil pengertian bahwa pendidikan hendaknya tidak memisahkan diri dengan kebutuhan masyarakat, pendidikan hendaknya menciptakan suasana yang mampu memberi kepuasan terhadap keinginan dan kebutuhan masyarakat sekitarnya, sehingga pendidikan mampu menjadi bagian yang tidak terpisahkan dengan kehidupan masyarakat. Hal itu dapat terwujud ketika pendidikan diarahkan dan dikembangkan sesuai kebutuhan masyarakat pada saat itu, serta disesuaikan dengan potensi geografis masyarakatnya. Perlu juga pendidikan mengkombinasikan nilai nilai ketuhanan dan kemanusiaan, sehingga ana semacam hubungan yang erat antara pendidikan.(Translation et al., 2019)

Oleh karena itu banyak ahli sejarah mengakui perannya yang besar dalam pembaharuan pemikiran Islam di Indonesia, namun sayang namanya tak banyak disebut dalam wacana sejarah pergulatan pemikiran Islam di Indonesia. Sejarawan Deliar Noer menyatakan bahwa Ahmad Syurkati memainkan peran penting sebagai mufti. Sedangkan, sejarawan belanda, GF Pijper, dalam tulisanya "beberapa studi tentang sejarah Islam di Indonesia" menyebutkan bahwa syurkati dikenal sebagai seorang pembaru Islam di Indonesia. Pijper berpandangan bahwa yang benar-benar merupakan gerakan pembaharuan dalam pemikiran dan ada persamaannya dengan gerakan reformisme di Mesir adalah Gerakan Pembaharuan Al-Irsyad. Sedang Muhammadiyah, kata Pijper, sebetulnya timbul sebagai reaksi terhadap politik pemerintah Hindia Belanda pada waktu itu yang berusaha untuk menasranikan orang Indonesia. (Zainal Anshari, 2020).

Hal-hal itulah yang mendorong penulis untuk mengkaji konsep pendidikan Agama Islam menurut pemikiran Ahmad Surkati. Kapasitas intelektual Ahmad Surkati dalam bidang pendidikan Islam menjadi alasan penulis untuk mengangkat pemikiran dan gagasan pendidikannya. Ia dikenal sebagai figur yang memiliki integritas tinggi dalam dunia pendidikan, baik berskala nasional maupun internasional.

\section{METODE PENELITIAN}

Penelitian kepustakaan (library research) merupakan jenis penelitian yang digunakan dalam penelitian ini, yakni penelitian yang datanya dikumpulkan dan dihimpun dari macam-macam literature. Penelitian kepustakaan (library research) adalah penelitian yang tujuannya untuk menggabungkan informasi dan bahan dari sumber-sumber yang tersedia di perpustakaan seperti buku, jurnal, dokumen, catatan, ataupun laporan (Saiful Annur, 2014). Data-data yang dikumpulkan berasal dari riwayat, pemikiran dan tulisan-tulisan Syekh Ahmad Surkati sebagai data utama (primer) dan sumber-sumber lainnya yang relevan dengan pembahasan 
4723 Konsep Pendidikan Agama Islam Perspektif Pemikiran Syekh Ahmad Surkati - Asep Supriatna, Vina Febiani Musyadad, Alfian Syach, Diah Widiawati

DOI: https://doi.org/10.31004/edukatif.v3i6.1534

sebagai data sekunder. Sebelum melakukan telaah bahan pustaka, peneliti harus mengetahui terlebih dahulu secara pasti tentang dari sumber mana informasi ilmiah itu akan diperoleh. Adapun beberapa sumber yang digunakan antara lain; buku-buku teks, jurnal ilmiah,refrensi statistik,hasil-hasil penelitian dalam bentuk skripsi, tesis, desertasi,dan internet, serta sumber-sumber lainnya yang relevan. (Sanusi, 2016)

Sumber data dalam penelitian ini terbagi menjadi dua, yaitu sumber data primer dan sumber data sekunder. Diantara sumber rujukan primer dalam penelitian ini yaitu buku yang berjudul Tokoh-Tokoh Islam yang Berpengaruh Abad 20 karya Herry Mohammad, kemudian buku yang berjudul Ensiklopedia Tokoh Pendidikan di Dunia Islam Dan Indonesia karya Ramayulis dan Samsul Nizar, dan buku Tarjamat Al-Hayat al-Ustadz Ahmad al-Surkati al-Ansari al-Sudani, Manuskrip, karya Umar Sulaiman Naji. Alasan penulis memilih buku-buku tersebut sebagai sumber data primer, karena buku-buku tersebut dianggap relevan dengan objek yang akan diteliti dan dapat memberikan informasi yang otentik. Sedangkan sumber data sekunder dalam penelitian ini yaitu buku Sejarah Social Pendidikan Islam, karya Suwito dan buku Pendidikan Agama Islam Berbasis Kompetensi, karya Abdul Majid, dan Dian Andayani. Alasan peneliti memilih buku tersebut sebagai data sekunder, karena buku tersebut dianggap bisa membantu peneliti dalam mencari informasi yang sistematis dan akurat.

\section{PEMBAHASAN DAN HASIL PENELITIAN}

Secara etimologi pendidikan Islam sering disebut dengan istilah tarbiyyah, ta'dîb, ta'lim, atau istilah lain yang maknanya pun memiliki keunikan makna tersendiri, rabba-yarbu-tarbiyah : bermakna tambah dan berkembang, kata tarbiyah berasal dari rabba-yurbi-tarbiyah : bermakna tumbuh dan menjadi besar/dewasa, rabba-yarubbu-tarbiyah : bermakna memperbaiki, menguasai urusan, memelihara dan merawat. Sehingga bila diambil dari kata kerjanya ( $r a b b a)$, pendidikan Islam memiliki arti menumbuhkan, mengembangkan, memelihara, membesarkan dan menjinakkan.

Pada awal abad ke-20 M, pendidikan di Indonesia terpecah menjadi dua golongan. Pertama, pendidikan yang diberikan oleh sekolah-sekolah Barat (Hindia Belanda) yang sekuler yang tidak mengenal ajaran agama. Kedua pendidikan pondok pesantren yang hanya mengenal pendidikan agama saja. Dengan istilah lain, terdapat dua corak pendidikan, yaitu corak lama yang berpusat di pondok pesantren dan corak baru dari perguruan (sekolah-sekolah) yang didirikan oleh pemerintah Belanda (Muhaimin, 2012).

Kemunculan al-Irsyad dan Tarbiyatul Islamiyah dalam gerakan pembaruan pendidikan Islam terasa penting karena organisasi ini termasuk organisasi moderen dalam ukuran masyarakat Islam pada waktu itu. Belanda pada 11 Agustus 1915. Al-Irsyad merupakan pecahan dari organisasi Jamiat Khair, menurut Steenbrink dalam Deliar Noer, telah terjadi perpecahan di kalangan Jamiat Khair mengenai hak istimewa golongan sayyid. Mereka yang tidak setuju dengan penghormatan yang berlebihan bagi sayyid dikecam dan dicap sebagai reformis. Tokoh sentral pendiri al-Irsyad adalah al-'Allamah Syeikh Ahmad Surkati Al-Anshori, seorang ulama besar Mekkah yang berasal dari Sudan. Pada mulanya Syekh Surkati datang ke Indonesia atas permintaan perkumpulan Jami'at Khair -yang mayoritas anggota pengurusnya terdiri dari orang-orang Indonesia keturunan Arab golongan sayyid, dan berdiri pada 1905. (Effendi, 2019).

Tokoh yang paling berperan dalam peristiwa ini adalah Syaikh Ahmad Surkati, ia mengeluarkan fatwa tentang jaiz atau sahnya pernikahan yang menjawab pertanyaan Umar bin Said Sungkar ipar awad Sungkar Al-Urmei, mengenai apakah diperbolehkan ( $k u f u$ ) kawin yang tidak sepadan (kafa'ah) yakni tidak sepadannya seorang "syarifah" menikah dengan seorang "non Sayyid" meski sama-sama memeluk agama Islam dan meski persyaratan lainnya sudah terpenuhi. Menurut Ahmad Surkati Hukum kafa'ah seperti yang dikenal itu sepenuhnya tesingkir di Mesir, Sudan, di Hejaz dan di negara-negara Islam lainnya (Badjerei, 1996).

Syekh Ahmad Surkati nama lengkapnya adalah Ahmad bin Muhammad Surkati al-Kharraj alAnshari, ia lahir pada tahun 1872 di Afdu Dunggulah Sudan dari keluarga yang taat beragama. Ayahnya, Muhammad 
4724 Konsep Pendidikan Agama Islam Perspektif Pemikiran Syekh Ahmad Surkati - Asep Supriatna, Vina Febiani Musyadad, Alfian Syach, Diah Widiawati

DOI: https://doi.org/10.31004/edukatif.v3i6.1534

alAnshari adalah seorang ulama tamatan Al-Azhar Kairo Mesir. Secara bahasa, Surkati berasal dari bahasa Sudan yang berarti "banyak kitab" dalam bahasa sudan "sur" artinya kitab dan katti artinya banyak. Tandatanda kecemerlangan Surkati sudah tampak sejak usia dini. Pada masa kecilnya, ia dididik dengan pendidikan agama oleh orang tuanya. Ayahnya mendidiknya dengan memberikan pelajaran agama, membaca dan menulis al-Qur'an serta menghafalkannya. Ahmad Surkati belajar kepada ulama-ulama besar yang ada di Madinah dan Makkah sehingga mendapat gelar alAllamah dari majelis ulama Makkah dan pengajar tetap di Masjidil Haram. Karena prestasi dan ketinggian ilmunya Ahmad Surkati di undang ke Indonesia dan setelah itu beliau menetap di Indonesia, yang kemudian membentuk lembaga pendidikan Al-Irsyad (Effendi, 2019).

Pada saat usia 22 tahun ia menunaikan ibadah haji, lalu ia menetap di Madinah selama 4 tahun untuk menuntut ilmu seperti tafsir, hadits, dan fiqih. Kemudian ia pindah ke Makkah untuk melanjutkan pendidikan yang lebih tinggi selama 11 tahun. Pada tahun 1906 ketika berumur 34 tahun ia berhasil memperoleh ijazah tertinggi guru agama (al-allamah) dari pemerintah Istanbul, bahkan ia termasuk salah seorang diantara 4 orang guru agama di Arab Saudi. Karier guru dan ulamanya dimulai dengan menjadi guru di Masjidil Haram al Musyarafah, di sini ia tidak lama menjadi seorang guru karena kemudian ia pergi ke Indonesia untuk mengembangkan ilmu pengetahuan dan dakwah agama Islam serta mensosialisasikan pemikirannya. Di Indonesia kemudian ia membentuk lembaga pendidikan yang dinamakan dengan al-Irsyad. Adapun prinsip dari gerakan alIrsyad yaitu untuk mewujudkan kesetaraan di antara kaum muslimin berdasarkan al-Qur'an dan Sunnah serta mengikuti jalan yang benar untuk semua solusi masalah agama yang diperdebatkan.

Penelitian mengenai Syaikh Ahmad Surkati memang sudah banyak, namun khusus penelitian mengenai Kontribusi Pemikiran Syaikh Ahmad Surkati Dalam Pemberdayaan Sumber Daya Pembelajaran Dalam Peningkatan Mutu Berbasis Sekolah masih belum dibahas secara umum dan belum memberikan penjelasan dan uraian yang sistematis. Diantara karya-karya yang membahas Ahmad Surkati adalah:

1. Buku karya Bisri Affandi yang berjudul Syekh Ahmad Surkati (1874-1943) Pembaharuan dan Pemurnian Islam di Indonesia, diterbitkan diJakarta oleh Pustaka al-Kautsar pada tahun 1999. Buku ini membahas tentang biografi Syaikh Ahmad Surkati mulai dari aktivitas ditanah kelahirannya (Sudan), hingga di Indonesia. Di dalam buku tersebut dijelaskan tentang latar belakang keluarga dan pendidikan Surkati. Setelah kedatangannya di Indonesia lebih banyak dijelaskna mengenai hubungannya dengan gerakan AlIrsyad serta usaha pemurnian ajaran Islam.

2. Buku yang berjudul Studi tentang Sejarah Islam di Indonesia 1900-1950 karya G.F Pijper, yang diterjemahkan oleh Tudjiman dan Yessy Agustin. Dalam bahasan bab ketiga buku ini dijelaskan mengenai aktivitas tiga gerakan Reformasi Islam di Indonesia, yaitu Muhammadiyah yang didirikan Ahmad Dahlan, Al-Irsyad yang diketuai Surkati dan Persis. Dalam buku ini juga dijelaskan hubungan antara ketiganya. Mengenai Al-Irsyad, Pijper lebih banyak menjelaskan pendangan-pandangan Surkati dalam bentuk kutipan karyanya, salah satunya Surat al-Jawab dan Al-Wasiyat al-Amiriyya.

3. Buku yang berjudul Al-Irsyad Mengisi Sejarah Kemerdekaan Bangsa, ditulis oleh Hussein Badjerei. Dalam buku ini menjelaskan sejarah berdirinya dan perkembangan Al-Irsyad, peran Surkati dalam organisasi ini, dan hubungan Surkati dengan orang-orang pribumi yang memiliki pengaruh besar di Indonesia.

4. Jurnal yang berjudul Nilai-Nilai Kebangsaan Pendidikan Islam dalam Perspektif Syaikh Ahmad Surkati 2013, ditulis oleh Faizah Nurmaningtyas dalam jurnal ini membahas tentang bagaimana Syaikh Ahmad Surkati membangkitkan kesadaran muslim Indonesia akibat dari dampak penjajahan. Beliau menggunakan pendidikan sebagai media pemurnian dalam ajaran agama Islam.

5. Dakwah dan Pembaharuan Pendidikan Islam Syaikh Ahmad Surkati 2019, ditulis Abdul Kadir, dalam Jurnal ini membahas tentang dakwah dan pembaharuan pendidikan Islam Syaikh Ahmad Surkati. Beliau merupakan peletak dasar pendidikan yang awalnya tradisional menjadi modernis dan tidak meninggalkan corak ke-Islam-an yang kental serta teguh dalam prinsip diatas Al-Qur"an dan as-Sunnah Nabi saw. 
4725 Konsep Pendidikan Agama Islam Perspektif Pemikiran Syekh Ahmad Surkati - Asep Supriatna, Vina Febiani Musyadad, Alfian Syach, Diah Widiawati

DOI: https://doi.org/10.31004/edukatif.v3i6.1534

6. Konstruksi Pemikiran reformasi Islam Ahmad Surkati, ditulis Rusydi Baya"egub, dalam jurnal ini membahas peran beliau dalam pembaharuanpemikiran di Indonesia. Pemikiran Syaikh Ahmad Surkati dalam kerangka tajdid dibidang keagamaan mengemukakan konsep kafae ah dan musawah yang merupakan perlawanan Ahmad Surkati terhadap diskriminasi antara keturunan Arab alawi dan non Alawi.

7. Peranan Syaikh Ahmad Surkati dalam perkembangan Islam di Jawa 1911-1943, ditulis oleh Rahmayani Samfirna, dalam Skripsi ini membahas Usaha-usaha yang dilakukan Syaikh Ahmad Surkati melihat keadaan masyarakat Arab dan Umat Muslim di Indonesia pada awal abad ke-20 yakni, Syaikh Amad Surkati melakukan usaha-usaha dalam bidang pendidikan, sosial dan keagamaan. Di bidang pendidikan beliau bersama Al-Irsyad membuka banyak Madrasah dengan Merombak pendidikan tradisional menjadi pendidikan modern dengan menggunakan kurikulum baru, dibidang sosial beliau berusaha untuk merealisasikan paham musawah (persamaan saesama muslim), sedangkan di bidang keagamaan, beliau menjelaskan tentang bid"eah, taqlid buta, khurafat dan lain-lainyang berlandaskan pada al-Qur'ean dan Hadist.

Pemikiran Syaikh Ahmad Surkati mampu mengubah tradisi sebagian masyarakat Arab di Indonesia, serta menjadi penggerak lahirnya tokoh-tokoh reformasi di kalangan masyarakat pribumi, bahkan muridmuridnya tidak hanya dari kalangan keturunan Arab dan pribumi, tetapi juga orang Belanda salah satunya Van der Plas seorang pejabat pemerintahan Belanda (Affandy, 1999). Ide dan pemikiran-pemikiran Syaikh Ahmad Surkati dituangkan dalam bentuk tulisan dan diterbitkan dalam bahasa Arab, Melayu, dan Belanda,10 dimuat dalam majalah dan surat kabar yang dapat dibaca oleh masyarakat umum. Salah satu majalah ini adalah Suluh Hindia yang diketuai H.O.S Tjokroaminoto dan Azzachratoel Islamiyah. Melalui media itu pemikiran Surkati semakin tersebar luas dalam masyarakat.(Pijper, 1984)

Menurut H.A.R. Gibb menyimpulkan bahwa Ahmad Surkati menyerap pemikiran Muhammad Abduh dalam basis perjuangannya, yaitu:

1) Pemurnian Islam dari pengaruh dan kebiasaan yang merusak (the purification of Islam from corrupting influence and practices).

2) penyusunan kembali pendidikan tinggi bagi umat Islam (the reformation of muslim higher education).

3) Mempertahankan Islam dari pengaruh Eropa dan serangan orang Nasrani (the defence of Islam againts European influence and Christian attack). (Effendi, 2019)

G. F. Pijper yang pernah belajar agama tafsir dan fikih pada Syaikh Ahmad Surkati mengatakan bahwa adanya persamaan anatara Syaikh Ahmad Surkati dan KH. Ahmad Dahlan tentang Muhammadiyah, organisasi yang perjuangannya berada dalam satu mata rantai dengan ide pembaharuan dan pemurnian Islam yang bersumber dari Ibn Taymiyah dan Ibn Qayyim. Keduanya menentukan sandaran perjuangan yang berbeda. Ahmad Surkati di wilayah masyarakat Arab dan Ahmad Dahlan pada masyarakat lainnya.

Semangat pembaruan dan pemurnian yang digalang Surkati termaktub dalam Mabadi al-Irsyad yang dirumuskan oleh dirinya dan para guru al-Irsyad dari Timur Tengah. Beberapa isinya sebagai berikut: Pertama, mengesakan Allah dengan sebersih-bersihnya dari segala hal yang berbau syirik, dan mengikhlaskan ibadah dan memohon pertolongan dalam segala urusan hanya kepada-Nya. Kedua, mewujudkan kemerdekaan dan persamaan di kalangan kaum muslimin dan berpedoman kepada Al Qur'an, al-Sunnah, perbuatan para imam yang sah dan perilaku ulama salaf dalam persoalan khilafiyah (perbedaan pendapat). Ketiga, memberantas taklid buta tanpa sandaran akal dan dalil. Keempat, menyebarluaskan ilmu pengetahuan, kebudayaan Arab-Islam dan budi pekerti yang diridhai Allah, dan keenam, berusaha mempersatukan kaum Muslimin dan bangsa Arab sesuai dengan kehendak Allah. (Nurmaningtyas, 2013)

Dalam menyusun program, beliau mempelajari dulu apa yang terjadi dalam masyarakat terlebih dulu. Program yang dijalankan sesuai dengan Muhammad Abduh, yaitu transformasi pendidikan dan pemurnian ajaran Islam dari praktik-praktik menyimpang.

Menurut Azumardi Azra, pemikiran Ahmad Surkati tentang Pendidikan Islam di Indonesia adalah 
4726 Konsep Pendidikan Agama Islam Perspektif Pemikiran Syekh Ahmad Surkati - Asep Supriatna, Vina Febiani Musyadad, Alfian Syach, Diah Widiawati

DOI: https://doi.org/10.31004/edukatif.v3i6.1534

dengan mempelopori mendirikan lembaga pendidikan al-Irsyad, yang mempunyai prinsip gerakan sebagai berikut:

1. Untuk mengukuhkan doktrin persatuan dengan membersihkan shalat dan doa dari kontaminasi unsur politheisme.

2. Untuk mewujudkan kesetaraan di antara kaum muslim dan mencari dalil yang shahih dalam al-Quran dan sunnah serta mengikuti jalan yang benar untuk semua solusi masalah agama yang diperdebatkan.

3. Untuk memerangi taqlid am (penerimaan membabi buta) yang bertentangan dengan dalil aqli dan naqli.

4. Untuk mensyiarkan pengetahuan alam sesuai Islam dan menyebarkan kebudayaan arab yang sesuai dengan ajaran Allah.

5. Mencoba untuk menciptakan pemahaman dua arah antara dua muslim yaitu Indonesia dan Arab. (Azra, 1999)

Ahmad Surkati mengatakan bahwa manusia adalah makhluk ciptaan yang sempurna dalam rangka mengemban tugas sebagai khalifah di muka bumi. Lebih lanjut Ahmad Surkati menyatakan bahwa kesempurnaan manusia tersebut perlu di berdayakan, pemberdayaan tersebut dapat dilakukan dengan pendidikan. Sebab dengan pendidikan potensi yang dimiliki oleh manusia dapat dimaksimalkan. Ahmad Surkati meyakini bahwa pendidikan dan pengajaran adalah kunci tercapai dan terciptanya kemajuan peradaban manusia. Kutipan di atas dapat dipahami bahwa kesempurnaan manusia dapat lebih ditingkatkan dengan pendidikan. Pendidikan juga akan mampu menjamin kemajuan peradaban manusia, dengan catatan pendidikan yang dilakukan dengan pengajaran yang baik berdasarkan al-Quran dan sunnah. Kata-kata bijak Ahmad Surkati yang berisi tentang pendidikan adalah sebagai berikut:

1. Pengajaran merupakan dasar dan pokok kemajuan dan kemuliaan dan kebersihan.

2. Bangsa yang mempunyai guru-guru mulia dan di letakkan pada posisi mulia, maka bangsa itu menjadi mulia.

3. Bangsa yang merendahkan / menghinakan guru-gurunya maka bangsa itu akan hina dan celaka.

4. Bangsa yang melalaikan urusan pendidikan / pengajaran maka generasi muda / bangsa itu akan mengalami kehinaan dan kerendahan serta kehancuran. (Effendi, 2019)

Inti dari kata bijak Ahmad Surkati di atas adalah perlunya manusia menyadari akan pentingnya pendidikan bagi kemajuan suatu bangsa, serat peradabannya. Sebaliknya bangsa yang tidak memperdulikan pendidikan akan mengalami kemunduran peradaban dan akhirnya hancur menjadi fosil-fosil peradaban.

Pemikiran Ahmad Surkati tentang Pendidikan Islam di Indonesia adalah dengan mempelopori mendirikan lembaga pendidikan al-Irsyad, yang mempunyai prinsip gerakan sebagai berikut: 1) untuk mengukuhkan doktrin persatuan dengan membersihkan shalat dan doa dari kontaminasi unsur politheisme. 2) untuk mewujudkan kesetaraan di antara kaum muslim dan mencari dalil yang shahih dalam al-Quran dan sunnah serta mengikuti jalan yang benar untuk semua solusi masalah agama yang diperdebatkan. 3) untuk memerangi taqlid am (penerimaan membabi buta) yang bertentangan dengan dalil aqli dan naqli. 4) untuk mensyiarkan pengetahuan alam sesuai Islam dan menyebarkan kebudayaan arab yang sesuai dengan ajaran Allah. 5) mencoba untuk menciptakan pemahaman dua arah antara dua muslim yaitu Indonesia dan Arab. (Azra, 1999)

Untuk mewujudkan hal tersebut menurut Ahmad Surkati pendidikan dan pengajaran harus diperbaiki.

\section{1) Sistem Pendidikan}

Ahmad Surkati menyatakan bahwa sistem pendidikan hendaknya mencerminkan kebutuhan masyarakat. Dalam arti pendidikan hendaknya mampu mengakomodasi kebutuhan yang ada dalam masyarakat, peningkatkan taraf hidup secara menyeluruh baik jasmani dan rohani dan yang tidak kalah penting adalah peningkatan pendidikan, di mana sistem pendidikan tersebut harus bersinergi dengan nilai-nilai ketuhanan dan kemanusiaan. Dapat diambil pengertian bahwa pendidikan hendaknya tidak memisahkan diri dengan kebutuhan masyarakat, pendidikan hendaknya menciptakan suasana yang mampu memberi kepuasan terhadap 
4727 Konsep Pendidikan Agama Islam Perspektif Pemikiran Syekh Ahmad Surkati - Asep Supriatna, Vina Febiani Musyadad, Alfian Syach, Diah Widiawati

DOI: https://doi.org/10.31004/edukatif.v3i6.1534

keinginan dan kebutuhan masyarakat sekitarnya, sehingga pendidikan mampu menjadi bagian yang tidak terpisahkan dengan kehidupan masyarakat. Hal itu dapat terwujud ketika pendidikan diarahkan dan dikembangkan sesuai kebutuhan masyarakat pada saat itu, serta disesuaikan dengan potensi geografis masyarakatnya. Perlu juga pendidikan mengkombinasikan nilai nilai ketuhanan dan kemanusiaan, sehingga ana semacam hubungan yang erat antara pendidikan. Menurut Ahmad Surkati sistem pendidikan harus mencerminkan perbaikan taraf kehidupan dan mampu memberikan perbaikan kondisi masyarakat secara lahir dan batin. Sistem pendidikan yang ideal menurutnya adalah sistem pendidikan yang ada mengandung dimensi ilahiyah dan dimensi insaniyah.

2) Tujuan dan Kurikulum Pendidikan

Tujuan pendidikan menurut Ahmad Surkati lebih mengacu kepada perlindungan terhadap manusia dari keterbelakangan dan keangkuhan diri sendiri, terutama dalam posisinya sebagai khalifah Allah di dunia ini. Kutipan tersebut mengindikasikan bahwa pendidikan mempunyai peranan penting dalam membantu individu keluar dari kungkungan kesengsaraan, kemunduran kualitas, kejatuhan nilai diri. Tujuan pendidikan juga mengisyaratkan perlunya perhatian khusus terhadap permasalah, problem, keadaan individu peserta didik, yang mengalami berbagai macam perbedaan latar belakang. Hal tersebut mengindikasikan bahwa pendidikan mempunyai peranan penting dalam membantu individu keluar dari kungkungan kesengsaraan, kemunduran kualitas, kejatuhan nilai diri serta keterbelakangan dan keangkuhan, dalam meniti dan mengemban kedudukan khalifah di bumi ini. Lebih lanjut tujuan pendidikan yang di kemukakan oleh Ahmad Surkati mengisyaratkan perlunya perhatian khusus terhadap permasalahan, problem, keadaan individu peserta didik, yang mengalamai berbagai macam perbedaan latar belakang, ekonomi, budaya, kemampuan, bakat dan potensi, maka dari itu perlindungan terhadap setiap individu peserta didik menjadi sangat penting demi tercapainya pribadi yang paripurna berdasarkan apa yang ada pada peserta didik

Keterbelakangan dan keangkuhan diri, merasa diri mampu memecahkan permasalahan, tantangan dalam meniti dan mengemban kedudukan khalifah di bumi ini. Lebih lanjut tujuan pendidikan yang di kemukakan oleh Ahmad Surkati mengisyaratkan perlunya perhatian khusus terhadap permasalahan, problem, keadaan individu peserta didik, yang mengalamai berbagai macam perbedaan latar belakang, ekonomi, budaya, kemampuan, bakat dan potensi, maka dari itu perlindungan terhadap setiap individu peserta didik menjadi sangat penting demi tercapainya pribadi yang paripurna berdasarkan apa yang ada pada peserta didik.

Adanya perbedaan individu berakibat kepada berbagai kondisi pembelajaran, metode, pendekatan yang semua itu bermuara kepada tercapainya tujuan pendidikan yang terfokus kepada pengembangan konsep tauhid, seperti keyakinan pada kesendirian Allah dalam melaksanakan penciptaan, pemeliharaan dan penertiban alam ini. Keyakinan akan kemandirian Allah akan kesempurnaan sifat-sifat-Nya, terakhir pendidikan hendaknya mengembangkan, memantapkan keyakinan peserta didik bahwa Allah adalah yang paling berhak untuk disembah, dan terlebih penting peserta didik mampu menghadirkan Tuhan dalam berbagai aktivitas kesehariannya.

Jakarta merupakan tempat berdirinya Al-Irsyad banyak didapatkan Sekolah Al-Irsyad yang pada umumnya lebih banyak jenisnya, sekolah-sekolah tingkat dasar, sekolah guru, disamping itu ada takhassus (pelajaran dua tahun), dimana para pelajar dapat mengadakan spesialisasi dalam bidang agama, pendidikan atau bahasa (Noer, 1982). Al-Irsyad dengan sekolah (Madrasahnya) membagi lima jenjang pendidikan yaitu:

1. Auwaliyah lama pelajaran 3 tahun ( tiga kelas)

2. Ibtidaiyyah, lama pelajaran 4 tahun (empat kelas)

3. Tajhiziah, lama pelajaran 2 tahun (dua kelas)

4. Mu'allimin, lama pelajaran 4 tahun (empat kelas )

5. Takhassus, lama pelajaran 2 tahun ( dua kelas ). (Yunus, 1992)

Jenjang pendidikan awwaliayah dan Ibtidaiyah merupakan tingkat pemula atau dasar, kemudian Tajhiziah merupakan tingkat lenjutan atau menengah sementara Muallimin mengarahklan murid untuk 
4728 Konsep Pendidikan Agama Islam Perspektif Pemikiran Syekh Ahmad Surkati - Asep Supriatna, Vina Febiani Musyadad, Alfian Syach, Diah Widiawati

DOI: https://doi.org/10.31004/edukatif.v3i6.1534

langsung mengajar sebagai asisten sedangkan Takhassus tingkat spesialisasi yang dipilih siswa. Penjenjangan tersebut seluruhnya dalam satu sekolah dan satu bangunan, ini disebabkan beragamnya siswa dilihat dari segi usia masingmasing. Siswa yang tingkat kecerdasannya tinggi dapat dipindahkan kekelas yang lebih tinggi, sehingga siswa ada yang selesai tidak sampai 15 tahun. Lembaga pendidikan Al-Irsyad pada dasarnya mengajarkan bahasa Arab sebagai mata pelajaran yang terpenting, sebagai alat untuk memahami Islam dari sumber-sumber pokoknya, buku-buku pelajaran yang berilustrasi gambar-gambar khususnya manusia telah dikenal di sekolah-sekolah, disamping itu diajarkan bahas Belanda dan olah raga (Badjerei, 1996).

Ramayulis memahami dan menyimpulkan tujuan pendidikan Islam yang didefinisikan oleh Ahmad Surkati lebih tertuju kepada pengembangan konsep tauhid bagi manusia. Adanya pengembangan konsep tauhid tersebut diharapkan manusia akan:

a) Membaca ayat-ayat qauliyah yang terdapat dalam wahyu Allah.

b) Membaca ayat-ayat kauniyah yang terdapat di alam raya.

c) Mengembangkan, memberdayakan, dan memelihara potensi alam sesuai dengan kehendak Allah. (Yunus, 1996)

Kesimpulan Ramayulis terhadap tujuan pendidikan yang didefinisikan oleh Ahmad Surkati di atas, menyiratkan bahwa sebenarnya pengembangan konsep tauhid dalam pendidikan akan memberi peluang kepada peserta didik untuk meneliti, observasi, dan berbagai uji coba terhadap berbagai penemuan dari hasil penelitian, atau mengadakan semacam pengembaraan intelektual dalam wadah institusi penelitian yang lebih terkonsep dan terorganisir.

Ahmad Surkati meyakini bahwa pendidikan merupakan hal yang sangat penting dan kunci bagi kemajuan kehidupan manusia sehingga menjadi media yang menurutnya paling efektif untuk merombak masyarakat. Dalam Surat al-Jawab ia menyatakan:

"Pendidikan merupakan dasar semua kemajuan dan merupakan inti dari semua kemuliaan, dan pangkal dari semua bentuk keberhasilan. Setiap bangsa yang guru-gurunya dalam posisi mulia maka bangsa itu akan menjadi mulia, dan sebaliknya bila guru dihina/direndahkan maka bangsa itu akan menjadi hina dan akan celaka. Bangsa yang melalaikan urusan pendidikan menyebabkan generasi mudanya akan terjerumus ke lembah kehinaan dan kerendahan, kemudian akan tertimpa kemusnahan dan kehancuran. Dan yang demikian itu merupakan ketetapan Allah yang diberlakuakan terhadap manusia." (Nurmaningtyas, 2013)

Dengan adanya pendidikan yang baik, suatu bangsa dapat mendayagunakan potensi yang mereka miliki dengan baik dan memanfaatkannya untuk kesejahteraan mereka. Demikian pula bangsa Indonesia. Tanpa adanya pendidikan yang baik, bangsa Indonesia akan tetap menjadi bangsa yang terbelakang karena tidak mampu mengolah sendiri segala kekayaan alam yang dimiliki akibat rendahnya kualitas sumber daya manusianya.

Pemikiran Ahmad Surkati dalam meningkatkan kualitas pembelajaran Islam harus melalui Lembaga Pendidikan yang terstruktur, yang diantaranya: 1) Membentuk penilik/semacam dewan pengawas pendidikan untuk melakukan inspeksi ke Lembaga-lembaga pendidikan di daerah agar tidak terjadi penyelewengan dan kesalahan dalam pelaksaan proses pendidikan. 2) Pengawas pendidikan hendaknya membuat laporan dari inspeksi yang telah dilakukan. 3) Lembaga pendidikan/ pengelola pendidikan hendaknya mengadakan pertemuan dalam membuatt prasarana pendidikan, kurikulum, maupun silabus. 4) Mengangkat pegawai perpustakaan. 5) Sekolah/ lembaga pendidikan hendaknya menyediakan buku-buku pelajaran/ buku khusus yang dapat dipinjamkan kepada siswa/ yang dapat dimanfaatkan oleh semua murid. 6) Mempunyai perpustakaan dengan koleksi yang lengkap. 7) Mempunyai media publikasi sendiri. 8) Mempunyai dewan komite sekolah yang anggotanya dari partisi pendidikan dan masyarakat. 9) Kepala sekolah dibebaskan dari tugas mengajar agar fokus kepada tugasnya sebagai kepala sekolah. 10) Memperhatikan penduduk sekitar sekolah. 11) Membuat pendidikan kejuruan sehingga siswa siap kerja dan mandiri. 12) Penyusunan kurikulum 
4729 Konsep Pendidikan Agama Islam Perspektif Pemikiran Syekh Ahmad Surkati - Asep Supriatna, Vina Febiani Musyadad, Alfian Syach, Diah Widiawati

DOI: https://doi.org/10.31004/edukatif.v3i6.1534

hendaknya memperhatikan kebutuhan masyarakat (Hasbullah, 2001).

Namun Ahmad Surkati sangat menyadari akan arti penting pembelajaran dan peran pendidik dalam pendidikan, maka berdasarkan hal itu sangatlah diperlukan kriteria tertentu kepada calon pendidik, yaitu, berakhlak mulia dan profesional.

Adapun pemikirannya tentang metode pengajaran Ahmad Surkati menerapkan banyak metode belajar yaitu: rihlah, diskusi, ceramah, dan praktek. Pendekatan yang digunakan Ahmad Surkati adalah memperhatikan muridnya dari segi budi pekerti dan intelektual, pemikiran yang mampu diterima oleh muridnya, pendekatan rasional, pendekatan personal, dan pendekatan tauhid (Suwito, 2005).

\section{Analisis Tentang Konsep Pendidikan Agama Islam Menurut Syekh Ahmad Surkati}

Setelah meneliti dan mencermati dari berbagai sumber yang di dapat tentang Konsep Pendidikan Agama Islam Menurut Syekh Ahmad Surkati, penulis dapat menganalisa sebagai berikut:

1. Konsep pengembangan pendidikan yang dilakukan oleh Ahmad Surkati pada Lembaga Pendidikan Islam adalah sebagai berikut:

a) Memperbaiki kondisi religius dan sosio ekonomi kaum muslim dengan mendirikan madrasah, rumah piatu, panti asuhan dan rumah sakit. Sebagaimana ia terapkan pada Lembaga sekaligus organisasi yang ia bina yaitu al-Irsyad

b) Menyebarkan reformasi Islam di antara para muslim melalui tulisan dan publikasi, pertemuan, kuliah, kelompok studi dan misi tertentu.

c) Membantu organisasi lain demi kepentingan bersama.

2. Diantara konsep program yang di jalankannya yaitu:

a) The purificatiom of Islam from Corrupting Influence and practice (pemurnian Islam dari pengaruh dan kebiasaan yang merusak)

b) The reformation of Muslim higher education (penyusunan kembali pendidikan tinggi bagi umat Islam)

c) The reformulation of Muslim higher education (reformulasi pendidikan tinggi bagi umat Islam)

d) The defence of Islam againt Eurephean influence and Christian attacks (mempertahankan Islam dari pengaruh Eropa dan serangan Nasrani).

Setelah dicermati pemikiran-pemikiran Ahmad Surkati ini mulai dikembangkan setelah mendirikan AlIrsyad. Beliau memfokuskan pemikirannya pada bidang pendidikan dan keagamaan, hal tersebut terbukti diantara pemikiran-pemikirannya dalam bidang pendidikan adalah merombak pendidikan tradisional menjadi modern dengan menggunakan kurikulum baru, selain pelajaran-pelajaran agama juga diajarkan pelajaranpelajaran umum, memberikan kebebasan murid-muridnya untuk mengeluarkan pendapat dan pemikirannya.

Menurut hemat penulis selain yang dijelaskan diatas, Syekh Ahmad Surkati juga merupakan pelopor dalam dunia pendidikan sekaligus sebagai bapak pembaharu, ini terbukti dengan adanya penjenjangan dalam intuisi pendidikan yang dilakukan oleh Syekh Ahmad Surkati, yang sebelumnya belum pernah ada di Indonesia. Beliau membuktikan keseriusannya dalam mengembangkan pengetahuan syiar Islam di Indonesia. Bahkan aspek yang sering kita lupakan dalam sistem pendidikan secara umum yaitu dalam masalah kelembagaan, sementara Syekh Ahmad Surkati lah pelopor terbentuknya sistem kelembagaan dalam dunia pendidikan. Ini sebuah kemajuan dalam dunia pendidikan. Besar kiranya kontribusi Syekh Ahmad Surkati dalam membina dan memajukan serta membenahi sistem pendidikan yang berkembang ditanah air kita Indonesia tercinta ini.

\section{KESIMPULAN}

Berdasarkan uraian sebelumnya, maka dapat diambil kesimpulan sebagai berikut: 1) Konsep pengembangan Pendidikan Agama Islam yang dilakukan oleh Syekh Ahmad Surkati pada lembaga pendidikan adalah memperbaiki kondisi religius dan sosio ekonomi kaum muslim dengan mendirikan madrasah, rumah 
4730 Konsep Pendidikan Agama Islam Perspektif Pemikiran Syekh Ahmad Surkati - Asep Supriatna, Vina Febiani Musyadad, Alfian Syach, Diah Widiawati

DOI: https://doi.org/10.31004/edukatif.v3i6.1534

piatu, panti asuhan dan rumah sakit, menyebarkan reformasi Islam di antara para muslim melalui tulisan dan publikasi, pertemuan, kuliah, kelompok studi dan misi tertentu, dan membantu organisasi lain demi kepentingan bersama. Dari konsep pengembangan tersebut, mengindikasikan agama tidak dapat tegak secara sempurna, tanpa didukung ekonomi yang mapan dan tingkat pendidikan yang memadai. Di samping itu untuk mewujudkan keadaan tersebut perlu kerjasama dengan organisasi lain yang mempunyai visi dan misi yang sama. 2) Diantara strategi yang digunakan Syekh Ahmad Surkati, berdasarkan pemikirannya dalam bidang pendidikan yang masih berkembang hingga sekarang adalah dapat kita lihat dalam beberapa aspek sebagai mana yang telah di bahas di muka, diantaranya konsep pendidikan, kurikulum, metode dan pendekatan, dan media pendidikan.

\section{DAFTAR PUSTAKA}

Affandy, B. (1999) Syaikh Ahmad Syukati Pembaharu Dan Pemurni Islam Di Indonesia 1874- 1943. Jakarta: Pustaka Al-Kutsa.

Azra, A. (1999) Esei-Esei Intelektual Muslim Dan Pendidikan Islam. Jakarta: Logos Wacana Ilmu.

Badar, M. (2012) "Reorientasi Strategi Pendidikan Islam Sebagai Upaya Peningkatan Mutu Sumber Daya Manusia," Al Hikmah, 2, Hal. 1-12.

Badjerei, H. (1996) Al- Irsyad Mengisi Sejarah Bangsa. Jakarta: Badan Penerbit Presto Prima Utama.

Effendi, M. N. (2019) "Pendidikan Al Irsyad Dan Kontribusinya," Jurnal Ilmiah Islam Dan Sosial, 20, Hal. 93-106.

Halim, I. (2014) "Pendidikan Islam Dalam Keluarga Menuju Masyarakat Madani,” Tesis, Hal. 1-86. Tersedia Pada: Http://Repositori.Uin-Alauddin.Ac.Id/1178/1/Rezki.Pdf?Cv=1.

Hasbullah (2001) Sejarah Pendidikan Islam. Jakarta: Raja Garfido Persada.

Jahar, A. S. (2018) "Filantropi Dan Keberlangsungan Ormas Islam," Al-Risalah, 16(01), Hal. 71. Doi: 10.30631/Al-Risalah.V16i01.337.

Muhaimin (2012) Wacana Pengembangan Pendidikan Islam. Jakarta: Bumi Aksara.

Noer, D. (1982) Gerakan Moderen Islam Di Indonesia 1900-1942. Jakarta: Lp3es.

Nurmaningtyas, F. (2013) "Nilai Kebangsaan Pendidikan Islam Dalam Perspektif Shaykh Ahmad Surkati," Epistemé: Jurnal Pengembangan Ilmu Keislaman, 8(2). Doi: 10.21274/Epis.2013.8.2.451-477.

Pijper, 0g.F. (1984) Beberapa Studi Tentang Sejarah Islam Di Indonesia 1900-1950. Jakarta: Ui-Press, Cet 1,.

Saiful Annur (2014) Metodologi Penelitian Pendidikan (Analisis Data Kuantitatif Dan Kualitatif). Palembang: Noer Fikri.

Sanusi, A. . (2016) Metodologi Penelitian Bisnis. Jakarta: Salemba Empat.

Sugeng Kurniawan (2014) “Madrasah Nizamiyahtentang, Kajian Pendidikan, Kurikulum,” Nur El-Islam, 1(2), Hal. 72-80.

Suwito (2005) Sejarah Sosial Pendidikan. Jakarta: Kencana Prenada Media Group.

Tabak (2014) Pendidikan Agama Islam Konsep Metode Pembelajaran Pai. Yogyakarta: Graha Ilmu.

Translation, T. H. E. Et Al. (2019) “Jurnal Ilmiah Islam Dan Sosial,” 20(2).

Yunus, M. (1992) Sejarah Pendidikan Islam Di Indonesia. Jakarta: Mutiara Sumber Widya.

Yunus, M. (1996) Sejarah Pendidikan. Jakarta: Hidakarya.

Zainal Anshari, A. (2020) “Jejak Historis Al-Irsyad Al-Islamiyah,” Akademika, 14, Hal. 37-48. 